\title{
New Cenozoic dragonflies from the Most Basin and Středohoří Complex volcanic area (Czech Republic, Germany)
}

\author{
Jakub Prokopa ${ }^{\mathrm{a}}$ Martina Pecharováa and André Nel $^{\mathrm{b}}$ \\ aFaculty of Science, Department of Zoology, Charles University in Prague, Praha 2, Czech Republic; \\ ${ }^{b}$ Muséum national d'histoire naturelle, Institut de systématique, évolution, biodiversité, ISYEB, UMR 7205 \\ CNRS UPMC EPHE, CP50, Sorbonne Universités, Paris, France
}

\begin{abstract}
Discovery of new dragonflies from Oligocene and Miocene deposits of the Most Basin and České Středohoří Complex volcanic area in northern Bohemia and Saxony (Germany) is reported. Aeshna zlatkokvaceki sp. nov. is the first described dragonfly from early Miocene salmonpink baked clays of Želénky near Duchcov. Its fore wing venation pattern seems to be closely related to that of Aeshna turoliana Riou and Nel, 1995, known from late Miocene of La Montagne d'Andance in Ardèche, France, and Aeshna solida Scudder, 1890, known from late Eocene of Florissant in Colorado, USA. A new occurrence of a libellulid dragonfly ?Onychothemis rihai in the Libkovice Member of Most Basin confirms the links to the Cypris Formation in Sokolov and Cheb basins reflecting similar habitats as was already shown on the basis of reconstructed palaeovegetation and shared thermophilous and accessory floristic elements. Other fragmentary fossil material from different localities are discussed.
\end{abstract}

\section{ARTICLE HISTORY}

Received 7 November 2015

Accepted 20 May 2016

\section{KEYWORDS}

Insecta; Odonata; Aeshnidae; Lindeniidae; Libellulidae; taxonomy

\section{Introduction}

The Cenozoic dragonflies from the territory of the Czech Republic are well known by number of significant species found in the Oligocene and Miocene deposits of the Krušné hory piedmont basins and Středohoří Complex volcanic areas (Figure 1) as well as Western Carpathians (e.g. Prokop and Nel 2000, 2002; Prokop et al. 2003, 2007). Handlirsch (19061908, p. 903) noticed the historical records of dragonfly nymphs from the Cypris Shale Formation in Jehličná near Sokolov situated in western Bohemia. His pioneer work was followed by other studies reporting rich associations of libellulid nymph exuviae from the same strata (Bachmayer 1952; Říha 1977; Prokop et al. 2003) or supposed gomphid nymph from the Bílina Mine in Most Basin (Kvaček et al. 2004, p. 28). However, all specimens of immature stages above or their exuviae from compressed fossils of lacustrine or deltaic deposits are hardly identifiable closer than on family level. Thus, our knowledge on

CONTACT Jakub Prokop jprokop@natur.cuni.cz EFaculty of Science, Department of Zoology, Charles University in Prague, Viničná 7, Praha 2 CZ-12844, Czech Republic; André Nel @anel@mnhn.fr @ Muséum national d'histoire naturelle, Institut de systématique, évolution, biodiversité, ISYEB, UMR 7205 CNRS UPMC EPHE, CP50, Sorbonne Universités, 45, rue Buffon, Paris 10 75005, France 


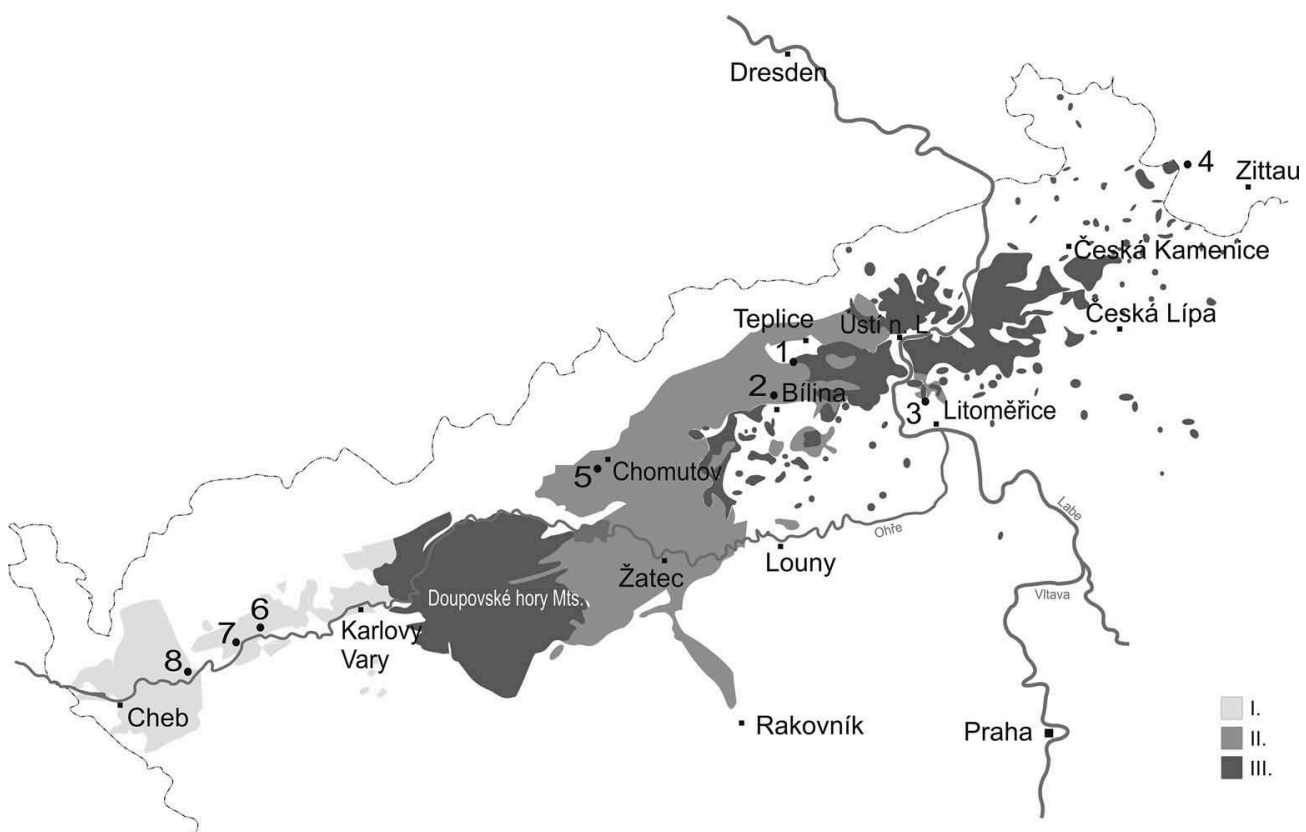

Figure 1. Map of Cenozoic dragonfly localities in the Krušné hory piedmont basins and volcanic areas. Abbreviations: I, Cheb and Sokolov basins; II, Most Basin; III, České středohoří Mts. and Doupovské hory Mts.; 1, Želénky near Duchcov; 2, Bílina mine; 3, Kundratice near Litoměřice; 4, Seifhennersdorf; 5, Libouš mine; 6, Jehličná near Sokolov; 7, Marie Majerová mine near Sokolov; 8, Pochlovice near Kynšperk n. Ohř́.

Cenozoic dragonflies is mainly based on adults, those wing veins are rather solid and the venation traits are commonly used in taxonomy by odonatologists.

Previous studies show that members of families Aeshnidae and Libellulidae unambiguously prevail in taphocoenoses (Prokop 2003). The occurrence of some taxa like members of libellulid Rhyothemistinae and contemporary Onychothemistinae living in the warm climate of intertropical areas may reflect the peak of Middle Miocene Optimum in Central Europe (Prokop et al. 2003). Furthermore, the pattern of distribution of some groups recently discovered in Neogene deposits of northern Bohemia, e.g. aeshnid Oplonaeshininae or Gomphaeshninae, support their significance in term of palaeogeography and reconstruction of past distribution in time (Prokop and Nel 2002).

Moreover, the traces of oviposition by damselflies on Quercus rhenana and Salix haidingeri Ettingshausen were recorded from Bílina mine in the Most Basin by Prokop et al. (2010) and Knor et al. (2012, 2015).

\section{Material and methods}

The present study is based on five specimens from the following institutional and private collections as Bílina Mine Enterprises (Bílina, Czech Republic), Senckenberg Naturhistorische Sammlungen (Dresden, Saxony, Germany) and Mgr. Tomáš Novotný coll., Nástup Tušimice quarry (Tušimice, Czech Republic). 
All specimens were observed with Olympus SZX-9 (Olympus Corporation, Tokyo, Japan) and Nikon 645 (Nikon Corporation, Tokyo, Japan) stereomicroscopes in a dry state. Line drawings of the pattern of wing venation were made directly through a stereomicroscope using a camera lucida. Photographs were taken with a Canon D550 (Canon Inc., Tokyo, Japan) digital camera with coupled macro lens EF $50 \mathrm{~mm}$. The original photographs were processed with Adobe Photoshop CS4 (Adobe Systems, San Jose, CA, USA), and for some images the focus-stacking software Helicon Focus Pro (Helicon Soft Ltd., Kharkov, Ukraine, Europe) was used.

The wing venation nomenclature follows Riek \& Kukalová-Peck (1984), amended by Kukalová-Peck (1991), Nel et al. (1993), Bechly $(1996,2007)$ and Bechly et al. (2001), with the following symbols used for the wing veins (symbols in capitals denote the longitudinal veins): ScP, subcostal posterior; RA/RP, radial anterior/posterior; IR1, IR2, intercalar radial vein; MA/MP, medial anterior/posterior; CuA/CuP, cubital anterior/posterior; $\mathrm{Ax0}, \mathrm{Ax1}$, Ax2, primary antenodal cross-veins.

\section{Taxonomy}

\section{Order ODONATA \\ Suborder ANISOPTERA}

Family AESHNIDAE Leach, 1815

Genus Aeshna Fabricius, 1775

Type species: Aeshna vulgatissima (Linnaeus, 1758) designated by Kirby, 1890

\section{Aeshna zlatkokvaceki sp. nov.}

(Figure 2(a, b))
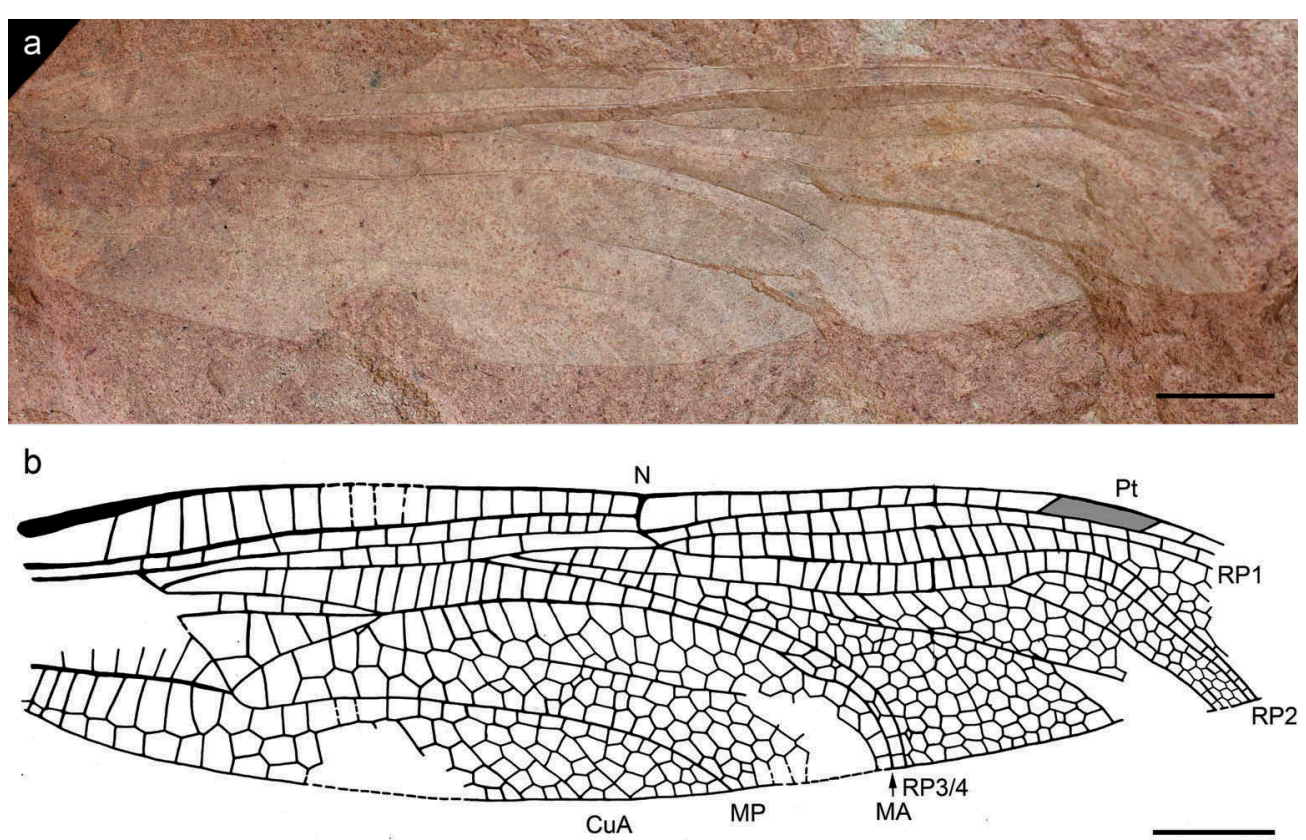

Figure 2. Aeshna zlatkokvaceki sp. nov. (Aeshnidae) (A) Photograph of holotype specimen SMMG CsT 1091 (Senckenberg Naturhistorische Sammlungen Dresden coll., Germany), imprint only; (B) line drawing of fore wing. Scale bars represent $5 \mathrm{~mm}$. 


\section{Etymology}

The epithet honours Prof. Zlatko Kvaček (Charles University, Praha), a world-famous palaeobotanist who systematically evaluated plant macrofossils from this locality.

\section{Holotype}

SMMG CsT 1091 (a nearly complete fore wing preserved in salmon-pink baked clay porcelanite), collection of Senckenberg Naturhistorische Sammlungen Dresden, Saxony, Germany.

\section{Age and outcrop}

Early Miocene (Burdigalian), Most Basin, Most Formation, Libkovice Member, Želénky near Duchcov (Figure 1), Czech Republic (see Kvaček and Hurník 2000).

\section{Description}

A nearly complete fore wing, with only median area and extreme apex missing; whole wing surface apparently hyaline; wing c.55 mm long (assumed from fragment) and $11.6 \mathrm{~mm}$ wide; distance from estimate base to nodus $c .26 .6 \mathrm{~mm}$; distance from nodus to wing apex, c.28.2 mm; nodus nearly midway between base and apex; distance from nodus to pterostigma $16.3 \mathrm{~mm}$; distance from pterostigma to apex about $7.5 \mathrm{~mm}$; pterostigma rather long, $4.4 \mathrm{~mm}$ long and $0.9 \mathrm{~mm}$ wide, covering approximately three cells and a half; pterostigmal brace slightly obliquely aligned with proximal side of pterostigma; 11 postnodal cross-veins, not well aligned with 13 visible subpostnodal cross-veins; 19 visible antenodal crossveins of first row between $C$ and ScP not aligned with the 17 visible corresponding antenodal cross-veins of second row between ScP and RA; 13 secondary antenodal cross-veins between Ax2 and nodus; four antenodal crossveins between $A \times 2$ and $A x 1 ; A x 14.6 \mathrm{~mm}$ and $A \times 210.9 \mathrm{~mm}$ from wing base; hypertriangle crossed by four cross-veins; median space not preserved; submedian space crossed by five cross-veins, subdiscoidal triangle three-celled; discoidal triangle elongate and divided into six smaller cells, its costal side being $8.1 \mathrm{~mm}$ long, distal side $6.9 \mathrm{~mm}$ long and proximal side $3.7 \mathrm{~mm}$ long; width of postdiscoidal area just behind discoidal triangle $3.4 \mathrm{~mm}$, width along posterior wing margin $7.2 \mathrm{~mm}$; three rows of cells in postdiscoidal area just distal of discoidal triangle; a short convex supplementary sector (trigonal planate) in postdiscoidal area, aligned with concave Mspl; Mspl well defined, nearly straight in its basal half but slightly curved in distal part; three rows of cells between Mspl and MP and three rows between Mspl and MA; two rows of cells and a short zigzagged supplementary vein in distal part of area between MA and RP3/4; bulge in distal part of MA ('aeshnid bulla') weak but present; four preserved Bq cross-veins; oblique vein ' $\mathrm{O}$ ' one cell distal of base of RP2; Rspl well defined and nearly straight; area between Rspl and IR2 wide, with four rows of cells in its widest part; space between IR2 and Rspl basally divided by oblique intercalary veinlets; IR2 smoothly curved distally and asymmetrically forked just basal of pterostigma, with three rows of cells between its branches; RP2 strongly curved posteriorly opposite proximal side of pterostigma; one row of cells between RP2 and anterior branch of IR2; IR1 present but zigzagged and short, about $8.7 \mathrm{~mm}$ long, beginning just below distal side of pterostigma; one row of cells between MP and CuAa in basal parts but five rows along posterior wing margin; 
CuAa with circa five posterior branches directed towards posterior wing margin; cubitoanal area broad with six rows of cells below CuAa.

\section{Discussion}

This fossil has all the autapomorphies of the family Aeshnidae as defined by Bechly (1996, 2007), i.e. 'aeshnid bulla' in distal part of MA in both pairs of wings; subdiscoidal triangle of both wings crossed by one crossvein; Rspl and Mspl distinctly curved with more than one row of cells between them and IR2 or MA, and area in between divided by oblique intercalary veins; more than two rows of cells in basal part of postdiscoidal area between level of distal angle of discoidal triangle and level of midfork; and hypertriangle traversed by at least three crossveins in fore wings. After the study of Ellenrieder (2002), this fossil fits into the clade 'Aeshnini' for the following synapomorphies: more than one cubito-anal crossvein; IR2 fork present; RP2 evenly curved; MA and RP3/4 not parallel, MA with a concave bend before wing margin; Mspl with a concave bend at distal portion; Rspl not parallel to IR2, with a concave bend. Its attribution to a precise genus in this clade is much more delicate to establish because missing body and hind wing characters are used as synapomorphies of different subgroups. The RP2 without marked convex bend at proximal end of pterostigma, is a plesiomorphic character state that would exclude affinities with the group (Anaciaeschna Selys, 1878 - A. isosceles - Andaeschna De Marmels, 1994 - Anax Leach, 1815 - Hemianax Selys, 1883), plus the fossil genus Merlax Prokop \& Nel, 2000, although we do not have apomorphies to support an attribution to one of the other genera of Aeshnini, i.e. Castoraeschna Calvert, 1952, Coryphaeschna Williamson, 1903, Remartinia Navás, 1911, Oreaeschna Lieftinck, 1937, and Aeshna Fabricius, 1775. Nevertheless, both this fossil and Aeshna differ from Castoraeschna, Oreaeschna, Coryphaeschna and Remartinia in the broad area between the branches of IR2, and forking of IR2 well basal of pterostigma. Within the genus Aeshna, this fossil shows strong similarities with Aeshna petalura Martin, 1908 or Aeshna shennong Zhang and Cai 2014 in the relatively narrow area between IR2 and Rspl with only four rows of cells, fork of IR2 just basal of level of pterostigma, broad area between MP and CuAa along fore wing margin (Martin 1908-1909; Zhang and Cai 2014). Nevertheless the lack of information on the genital characters prevents us from considering that this fossil is more closely related to these species than to the other modern Aeshna.

Among the fossil Aeshna species with a forked IR2, A. zlatkokvaceki sp. nov. differs from A. multicellulata Gentilini and Peters, 1993, A. ghiandonii Gentilini and Peters, 1993, A. oligocenica Nel, 1994 (in Nel et al. 1994), A. cerdanica Nel and Martinez-Delclos, 1994 (in Nel et al. 1994), A. andancensis Nel and Brisac, 1994 (in Nel et al. 1994), A. stavropolensis $\mathrm{Nel}$ et al., 2005, A. shanwangensis Li et al., 2011a, A. forficatum Li et al., 2011a and ?Aeshna sp. (in Prokop and Nel 2000), in the narrower area between Rspl and IR2. It differs from A. messiniana Gentilini and Peters, 1993 in the narrower area between forks of IR2, and straight Rspl (Gentilini and Peters 1993; Nel et al. 1994, 2005; Li et al. 2011a).

A. zlatkokvaceki sp. nov. is very similar to the Late Miocene Aeshna turoliana Riou and Nel 1995, known by a fore wing, with the only difference in the longer discoidal triangle in A. zlatkokvaceki divided into six cells instead of four (Riou and Nel 1995). It is also similar to the Late Eocene Aeshna solida Scudder, 1890, which has its fore wing discoidal 
triangle divided into five cells (Scudder 1890). It is c.44 mm long, instead of c.50 $\mathrm{mm}$ in $A$. zlatkokvaceki.

\section{Remarks}

(1) Aeshna vösendorfensis Papp and Mandl, 1951 is too incomplete to be compared to A. zlatkokvaceki sp. nov. It seems to differs from A. zlatkokvaceki sp. nov. in the narrow space between MP and CuA near posterior wing margin (Papp and Mandl 1951: fig 1).

(2) Barbu (1939) described and figured a Miocene hind wing he attributed to 'Aeshna polydore' Heer, 1849. It is too poorly described to be compared to our fossil.

(3) A. zlatkokvaceki sp. nov. shows some similarities with Epiaeschna Hagen, 1875 (and especially with the Miocene species H. matutina (Zhang 1989) in the general venation, but it differs from this genus in the more pronounced concave bend of MA before wing margin (see Li et al. 2011b).

Aeshnidae genus incertae sedis

cf. Aeshna sp.

(Figure 3(a, b))

\section{Material}

SMMG Ku 398 (a nearly complete fore wing lacking base and parts along posterior margin, preserved in brown diatomite), collection of Senckenberg Naturhistorische Sammlungen Dresden, Saxony, Germany.

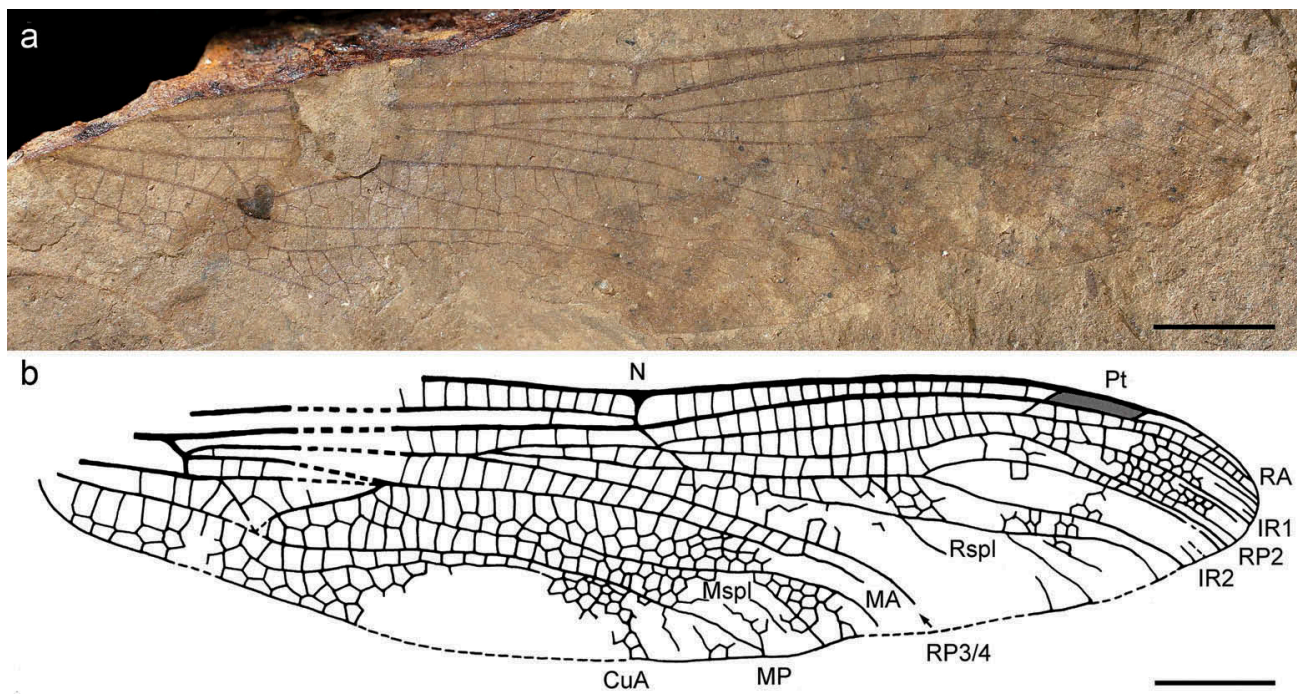

Figure 3. cf. Aeshna sp. (Aeshnidae), (A) photograph of specimen SMMG Ku 398 (Senckenberg Naturhistorische Sammlungen Dresden coll., Germany), imprint only; (B) line drawing of fore wing. Scale bars represent $5 \mathrm{~mm}$. 


\section{Age and outcrop}

Early Oligocene (Rupelian-Chattian), Ústí Formation, Středohoří Complex, Kundratice near Litoměřice (Figure 1), Czech Republic (see Kvaček and Walther 1998).

\section{Description}

A nearly complete fore wing, with only basal anterior area and parts along posterior wing margin missing; wing surface apparently hyaline; wing c.52 mm long (assumed from fragment) and $17.5 \mathrm{~mm}$ wide; distance from estimated base to nodus c.25.3 mm; distance from nodus to wing apex, c. $26.6 \mathrm{~mm}$; nodus nearly midway between base and apex; distance from nodus to pterostigma $17.4 \mathrm{~mm}$; distance from pterostigma to apex about $5.6 \mathrm{~mm}$; pterostigma rather long, $4.0 \mathrm{~mm}$ long and $0.9 \mathrm{~mm}$ wide, covering approximately five cells; pterostigmal brace obliquely aligned with proximal side of pterostigma; 20 postnodal cross-veins, not well aligned with 16 visible subpostnodal cross-veins; 12 visible antenodal crossveins of first row between $\mathrm{C}$ and ScP not aligned with one visible corresponding antenodal cross-veins of second row between ScP and RA; hypertriangle crossed by three or more cross-veins; median space free, partly preserved; submedian space crossed by two cross-veins, subdiscoidal triangle twocelled; discoidal triangle elongate and divided into five small cells, its costal side being $6.6 \mathrm{~mm}$ long, distal side $5.9 \mathrm{~mm}$ long and proximal side $2.8 \mathrm{~mm}$ long; width of postdiscoidal area just behind discoidal triangle $3.4 \mathrm{~mm}$, width along posterior wing margin $7.2 \mathrm{~mm}$; three rows of cells in postdiscoidal area just distal of discoidal triangle; convex supplementary sector (trigonal planate) in postdiscoidal area, aligned with concave Mspl; Mspl well defined, undulated; two or three rows of cells between Mspl and MP and also between Mspl and MA; bulge in distal part of MA ('aeshnid bulla') apparently weaker than in Aeshna zlatkokvaceki sp. nov., but it is too poorly preserved to be accurately described; five preserved Bq cross-veins; oblique vein ' $\mathrm{O}$ ' one cell distal of base of RP2; Rspl well defined and nearly straight; area between Rspl and IR2 with three rows of cells in its widest part; IR2 smoothly curved distally and asymmetrically forked $5.0 \mathrm{~mm}$ proximad of pterostigma, with three rows of cells between its branches; RP2 strongly curved posteriorly opposite proximal side of pterostigma; one row of cells between RP2 and anterior branch of IR2; IR1 nearly straight beginning just below proximal posterior edge of pterostigma; one row of cells between MP and CuAa in basal parts, but with about five or six along posterior wing margin; CuAa with circa six posterior branches directed towards posterior wing margin, but not preserved; cubitoanal area poorly preserved, but distinctly broad with about seven rows of cells below CuAa.

\section{Discussion}

This fossil has all the autapomorphies of the family Aeshnidae as listed above and defined by Bechly $(1996,2007)$. It shares with representatives of the clade 'Aeshnini' the following synapomorphies: more than one cubito-anal crossvein; IR2 fork present; RP2 evenly curved; MA and RP3/4 not parallel, MA apparently with a concave bend before wing margin; Mspl with a concave bend at distal portion. But its Rspl quite parallel to IR2, without a concave bend would contradict this attribution, even if some modern Aeshna have also a nearly straight Rspl. It differs from Aeshna zlatkokvaceki sp. nov. in the presence of only three rows of small cells between Rspl and IR2 instead of 
four rows of larger cells. Its precise attribution to an Aeshnidae genus is very delicate for the poor preservation of the distal parts of areas between MP and CuA, MA and RP3/4, and area between the branches of IR2. We prefer to maintain it as an Aeshnidae incertae sedis, maybe related to Aeshna.

\section{Aeshnidae genus incertae sedis Genus and species undetermined}

(Figure 4(a, b))

\section{Material}

Specimen No. ZD 282 (midpart of hind wing preserved in light brown claystone), deposited in the collections of the Bílina Mine Enterprises, Bílina, Czech Republic.

\section{Age and outcrop}

Early Miocene (Burdigalian), Most Basin, Most Formation, Holešice Member, Delta Sandy Horizon, Bílina mine near Bílina (Figure 1), Czech Republic (see Kvaček et al. 2004).

\section{Description}

Mid part of a hind wing, fragment c.22 $\mathrm{mm}$ long and $13.9 \mathrm{~mm}$ wide; eight preserved postnodal veins, not well aligned with subpostnodal crossveins; four visible antenodal crossveins not aligned with corresponding crossveins between ScP and RA; four preserved crossveins between RA and RP basal of subnodus; well defined and curved Mspl with four rows of cells between it and MA; two rows of cells between MA and RP3/4 in distal part of this area; one visible $\mathrm{Bq}$ crossvein; oblique crossvein ' $\mathrm{O}$ ' just distal of base of RP2; Rspl well defined and slightly curved; several secondary posterior branches of IR2 between it and Rspl.

\section{Discussion}

The shape of the Mspl, Rspl, and distal part of MA are characteristic of an Aeshnidae. The very broad distal part of cubital area indicates it is a hind wing. Unfortunately the lack of
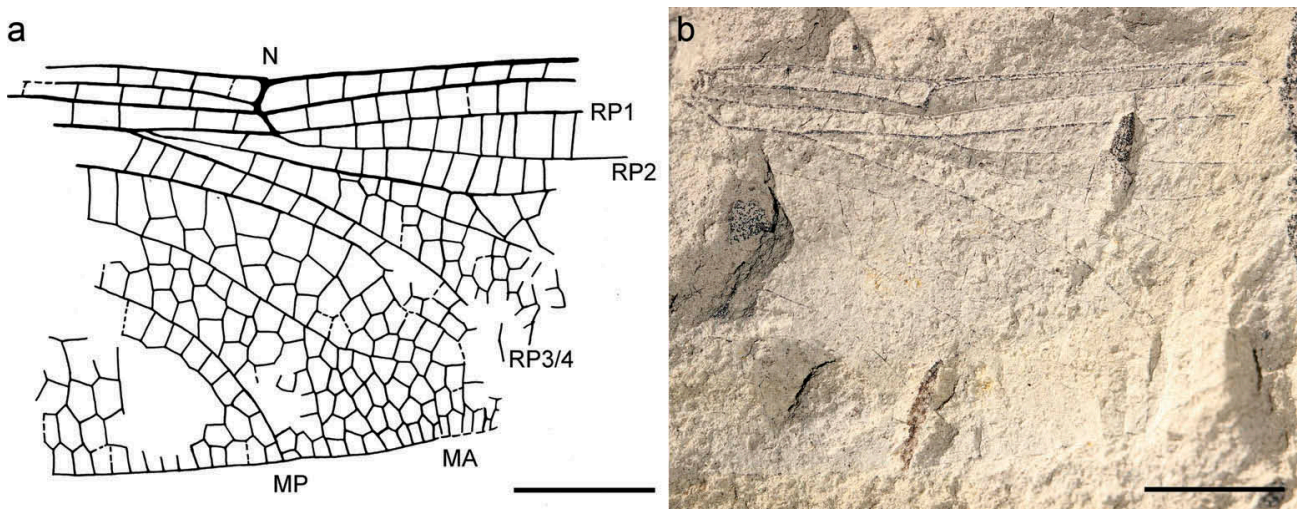

Figure 4. Genus and species indet. (Aeshnidae), (A) line drawing of fore wing; (B) photograph of specimen ZD 282 (Bílina Mine Enterprises, Bílina coll., Czech Republic). Scale bars represent $5 \mathrm{~mm}$. 
information on the discoidal space, distal part of RP2 and IR2, pterostigma and IR1 prevents precise definition of the affinities of this fossil. It differs from Merlax bohemicus Prokop and Nel, 2000 from the same locality in the presence of only four rows of cells in area between Mspl and MA. It better fits with the other undetermined aeshnid wing also described by Prokop and Nel (2000, p. 430-431, figs 5, 6); but some doubt remains about the identity of the two fossils.

Clade GOMPHIDES Bechly et al., 1998

Family LINDENIIDAE Jacobson \& Bianchi, 1905

?Ictinogomphus species undetermined

(Figure 5(a, b))

?lctinogomphus Cowley, 1934: Prokop and Fikáček 2007, p. 210, fig. 1

\section{Material}

SMMG SaT 532, collection of Senckenberg Naturhistorische Sammlungen Dresden, Saxony, Germany.

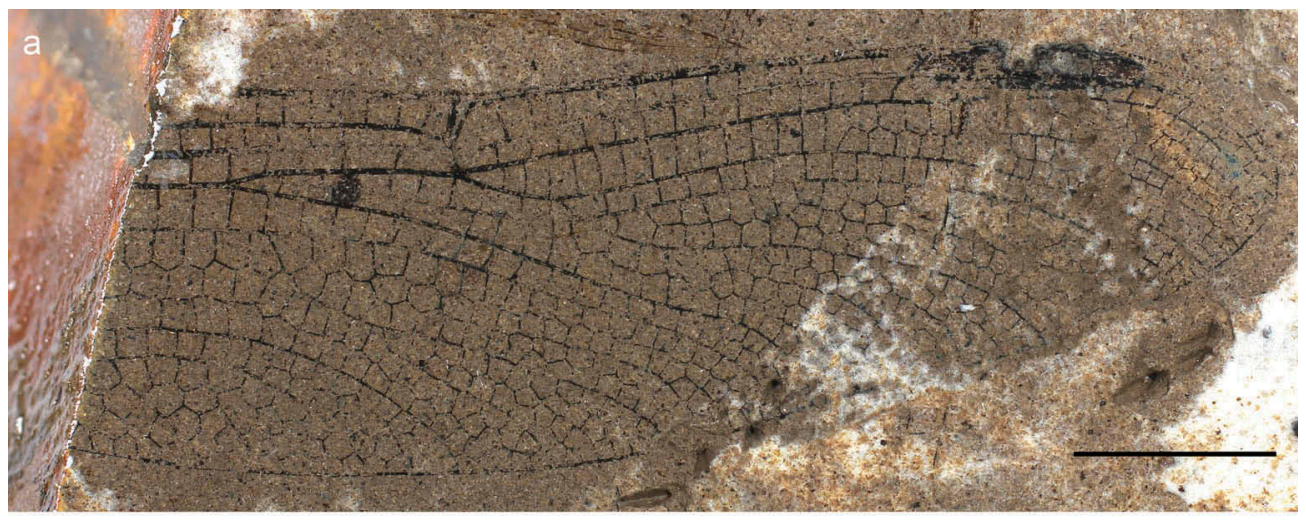

b

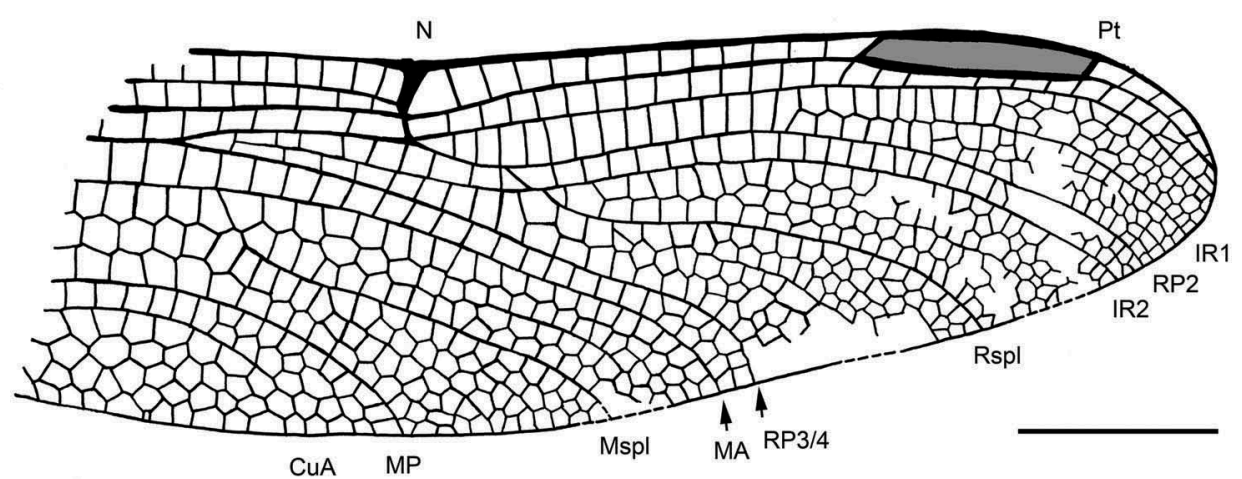

Figure 5. ?lctinogomphus species indet. (Lindeniidae), (A) Photograph of specimen under film layer of ethyl alcohol SMMG SaT 532 (Senckenberg Naturhistorische Sammlungen Dresden coll., Germany); (B) line drawing of fore wing. Scale bar represent $5 \mathrm{~mm}$. 


\section{Age and outcrop}

Early Oligocene (Rupelian), Seifhennersdorf (Saxony, Germany) (Figure 1), inter-bedded brownish diatomite within the magmatic complex, equivalent of the Loučen Formation (see Walther and Kvaček 2007).

\section{Description}

Distal two-third of a hyaline fore wing, about $29.2 \mathrm{~mm}$ long, $9.4 \mathrm{~mm}$ wide; distance between nodus and pterostigma $11.5 \mathrm{~mm}$, between pterostigma and wing apex $3.2 \mathrm{~mm}$; pterostigma $5.7 \mathrm{~mm}$ long, $1.14 \mathrm{~mm}$ wide, covering six cells; pterostigmal brace oblique; three rows of cells in postdiscoidal area between triangle and posterior branch of MA; MA and IR2 both with a very distinct diverging posterior branch; 12 postnodal cross-veins, not aligned with postsubnodal cross-veins; two rows of cells between MA and RP3/4 near posterior wing margin; four rows of cells between MP and $\mathrm{CuA}$ along posterior wing margin; five rows of cells between $\mathrm{CuA}$ and posterior wing margin.

\section{Discussion}

Prokop \& Fikáček (2007, p. 210) briefly noticed the present specimen in the annotated list of insect fossils from Seifhennersdorf locality in Saxony (Germany) without giving a formal description and broader discussion. This fossil wing can be accurately attributed to the gomphid group Lindeniini Jacobson and Bianchi, 1905 (or Lindeniidae sensu Bechly 1996, 2007) on the basis of the presence of a very distinct secondary branch of IR2, therefore IR2 appears to be dichotomously forked distal of the lestine oblique vein ' $\mathrm{O}$ '; and the presence of a secondary branch of MA too. As the basal structures of the wing are not preserved, its generic attribution is much more delicate. Nevertheless, affinities with all the genera listed in Lindeniini in Bridges (1994) can be excluded, except for the three genera Ictinogomphus Cowley, 1934, Gomphidia Selys, 1854, and Lindenia de Haan, 1826. More precisely, Sinictinogomphus Fraser 1939, Mitragomphus Needham 1944, and Cinitogomphus Pinhey 1964 are excluded because our fossil has three rows of cells in postdiscoidal area, instead of two (Fraser 1939; Needham 1944; Pinhey 1964); for the same reason plus Gomphidictinus Fraser 1942 and Diastatomma Burmeister, 1839 because it has a strong fork of MA (Fraser 1942); Cacoides Cowley, 1934 because it has no strong curve of RP2 between nodus and pterostigma and the pterostigma covering only six cells, instead of nine (Belle 1986); and Melanocacus Belle, 1986: for the same last reason (Belle 1986). Lastly the Cretaceous lindeniid genus Cratolindenia Bechly, 2000 differs from our fossil in the more distal positions of the posterior branches of MA and IR2, respectively below the subnodus and four cells basal of pterostigma, instead of being below base of IR2 and just distal of oblique vein ' $O$ ' (Bechly 2000). It is impossible to choose a more precise attribution of this fossil between the three genera Ictinogomphus, Gomphidia, and Lindenia.

Ictinogomphus is distributed in Eastern Palaearctic, Indo-Malaysian, Australasian, and Afrotropical regions; Gomphidia in Eastern Palaearctic, Indo-Malaysian, and Afrotropical regions; and Lindenia in Palaearctic region. A Lindeniinae genus incertae sedis is already recorded from the Oligo-Miocene of Turkey and an abdomen is attributed to the genus Ictinogomphus from the Lower Miocene of Japan (Yasuno 1990; Nel and Paicheler 1994a). Ictinogomphus fur (Hagen 1863) is a poor fossil from the Oligocene of Rott (Germany), of uncertain affinities. The presence of two Lindeniini in the Oligocene of 
Europe supports a rather warm palaeoclimate for this period and a broader past distribution of this gomphid group.

Family LIBELLULIDAE Leach, 1815

Genus Onychothemis Brauer, 1868

Type species: Onychothemis abnormis Brauer, 1868

?Onychothemis rihai Prokop et al., 2003

(Figure 6(a, b))

\section{Material}

Specimen no. TN1 stored in private collection of Mgr. Tomáš Novotný, Nástup Tušimice quarry, Czech Republic.

\section{Age and outcrop}

Early Miocene (Burdigalian), Libouš mine (Figure 1), Spořice district, Most Basin, Most Formation, Libkovice Member, about 15-20 m above the Crandallite Horizon C1 sensu Matys-Grygar \& Mach (2013).

\section{Description}

Fore wing. Wing hyaline, $51.6 \mathrm{~mm}$ long; distance between base and nodus $26.6 \mathrm{~mm}$; between nodus and apex $25.3 \mathrm{~mm}$, nodus nearly midway between base and apex; distance
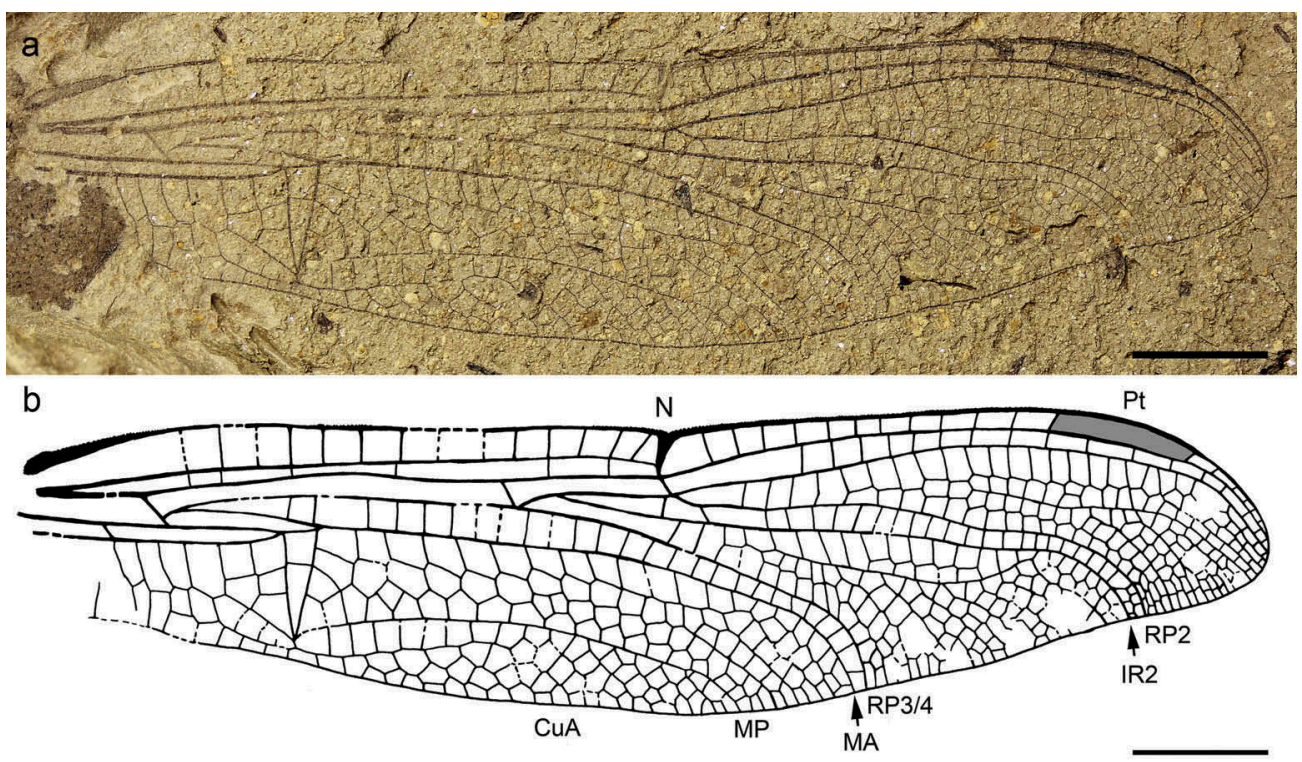

Figure 6. ?Onychothemis rihai Prokop et al., 2003 (Libellulidae), (A) Photograph of specimen No. TN1 (Tomáš Novotný coll., Nástup Tušimice quarry, Czech Republic); (B) line drawing of fore wing. Scale bar represent $5 \mathrm{~mm}$. 
between nodus and pterostigma $16.3 \mathrm{~mm}$, between pterostigma and apex $4.3 \mathrm{~mm}$; pterostigma $5.9 \mathrm{~mm}$ long, $0.9 \mathrm{~mm}$ wide, with costal and posterior sides maximally widened in middle; no oblique pterostigmal brace; pterostigma covering three and a half cells; 11 postnodal cross-veins, not well aligned with eight corresponding postsubnodal cross-veins; 'libellulid gap' long; second oblique cross-vein between RP1 and RP2 only weakly oblique; 15 preserved antenodal cross-veins of first row, apparently all well aligned with those of second row, last antenodal cross-vein incomplete; distance between first antenodal crossvein and wing base $6.9 \mathrm{~mm}$; distance between arculus and wing base $5.6 \mathrm{~mm}$; arculus opposite an antenodal cross-vein (probably second one, but incompletely preserved); number of cross-veins between RA and RP, between arculus and nodus, unknown; one preserved $\mathrm{Bq}$ cross-vein between IR2 and RP2; distance between arculus and nodus $20.6 \mathrm{~mm}$; base of RP 3/4 and that of IR2 $16.9 \mathrm{~mm}$ distal of arculus; sectors of arculus (bases of RP and MA) clearly fused basally; median and submedian spaces free of crossveins, subdiscoidal cell $3.6 \mathrm{~mm}$ long, $2.2 \mathrm{~mm}$ wide and divided into five cells; discoidal triangle narrow transverse, divided into two cells, length of its costal side $1.3 \mathrm{~mm}$; proximal side $4.3 \mathrm{~mm}$ long, distal side $5.0 \mathrm{~mm}$ long; $2-3$ rows of cells in anal area; $3-5$ rows of cells in cubito-anal area, width of cubito-anal area $2.5 \mathrm{~mm}$; CuA not well defined and reaching posterior wing margin about $3.0 \mathrm{~mm}$ basal of nodus; MP nearly straight and reaching posterior wing margin $3.2 \mathrm{~mm}$ distal of nodus; four rows of cells in postdiscoidal area just distal of discoidal triangle; postdiscoidal area narrower ( $2.8 \mathrm{~mm}$ wide) in its middle part than near discoidal triangle (3.9 mm wide); Mspl straight, with one row of cells between it and MA; RP 3/4 and MA basally nearly straight but distally curved and nearly perpendicular to posterior wing margin; RP2 aligned with subnodus; oblique cross-vein ' $\mathrm{O}$ ' $1.1 \mathrm{~mm}$ distal of subnodus; IR2 and RP2 with two strong undulations; IR2 and RP2 distally curved and nearly perpendicular to wing margin; area between IR2 and RP3/4 rather wide, with a nearly straight vein Rspl; two rows of cells between Rspl and IR2; area between RP1 and RP2 rather wide, but incompletely preserved, no visible 'reversed libellulid oblique vein' between RP2 and RP3/4.

\section{Discussion}

This fore wing is very similar to that of the holotype of ?Onychothemis rihai Prokop et al. 2003 from the Lower Miocene of Czech Republic (Prokop et al. 2003). The visible differences are very few, namely pterostigma covering three and a half cells, instead of three cells in the later; discoidal triangle crossed by only one vein instead of two. In particular, the shape of all the main veins and areas between them are identical in the two fossils. The only problem with the new fossil is the lack of preservation of the basal part of the antenodal area so that the presence of the two most basal antenodal crossveins cannot be ascertained even if some traces of the second one opposite to the arculus are probably present. The slightly longer wing of the new specimen $(46.2 \mathrm{~mm}$ long instead of $43 \mathrm{~mm}$ in the holotype of ?O. rihai) is also compatible with an intraspecific variation (Prokop et al. 2003). Moreover, the occurrence of ?Onychothemis rihai in the Libkovice Member of Most Basin confirms links to Cypris Formation in Sokolov and Cheb basins and possibly similar habitat as was already demonstrated on the basis of reconstructed palaeovegetation and number of shared thermophilous and accessory floristic elements (Teodoridis and Kvaček 2006). 


\section{Conclusions}

The present discoveries confirm that the European anisopteran fauna was very diverse during the Oligocene-Miocene, known through numerous representatives of the modern families Aeshnidae, Gomphidae and Libellulidae (Nel and Paicheler 1993, 1994a; Nel et al. 1994). However, the other anisopteran families remain much rarer in the Oligocene-Miocene European outcrops, as was already noticed (Nel and Paicheler 1992, 1994b). The proportions between the families were probably nearly the same as nowadays in this region, even if several of the Oligocene-Miocene genera are now extinct and/or related to taxa from warmer intertropical areas.

\section{Acknowledgements}

We are grateful to Dr Markus Wilmsen, Mr Manuel Röthel and Mr Ronald Winkler (all from Senckenberg Naturhistorische Sammlungen Dresden), Mgr Tomáš Novotný (Nástup Tušimice quarry) and Zdeněk Dvořák (Bílina Mine enterprise) for access to their collections and loan of the specimens from institutional and private collections.

\section{Disclosure statement}

No potential conflict of interest was reported by the authors.

\section{Funding}

This work was supported by the Institutional Research Support grant of the Charles University, Prague [SVV 260 313/ 2016]; Grant Agency of the Czech Republic [14-23108S].

\section{References}

Bachmayer F. 1952. Fossile Libellenlarven aus miozänen Süsswasserablagerungen. Sber Oesterr Akad Wiss, Math-Naturwiss KI. 161:136-140.

Barbu IZ. 1939. Insectes fossiles du Tertiaire de l'Ollénie. Bull Soc Roumaine Geol. 4:119-128.

Bechly G. 1996. Morphologische Untersuchungen am Flügelgeäder der rezenten Libellen und deren Stammgruppenvertreter (Insecta; Pterygota; Odonata), unter besonderer Berücksichtigung der Phylogenetischen Systematik und des Grundplanes der *Odonata. Petalura (Böblingen). 2:1-402.

Bechly G. 2000. Two new dragonfly species (Insecta: odonata: Anisoptera: Araripegomphidae and Lindeniidae) from the Crato limestone (Lower Cretaceous, Brazil). Stutt Beit Natur (B). 296:1-16.

Bechly G. 2007. Phylogenetic systematics of Odonata. - homepage on the Internet. Available from: https://dl.dropboxusercontent.com/u/13756162/Website/odonata/system.htm.

Bechly G, Nel A, Martinez-Delclos X, Fleck G. 1998. Four new dragonflies from the Upper Jurassic of Germany and the Lower Cretaceous of Mongolia (Anisoptera: Hemeroscopidae, Sonidae, and Proterogomphidae). Odonatologica. 27:149-187.

Bechly G, Nel A, Martínez-Delclòs X, Jarzembowski EA, Coram R, Martill D, Fleck G, Escuillié F, Wisshak MM, Maisch M. 2001. A revision and phylogenetic study of Mesozoic Aeshnoptera, with description of several new families, genera and species (Insecta: odonata: Anisoptera). N Paläont Abh. 4:1-219.

Belle J. 1986. New World Lindeniinae, with Melanocacus interioris gen. nov, spec. nov. (Gomphidae). Entomol Bericht. 46:97-102. 
Brauer F. 1868. Verzeischnissder bis jetzt Bekannten Neuropteren in Sinne Linne's. Verhandlungen der Zoologische Botanischen Wereins in Wien. 18:711-742.

Bridges CA. 1994. Catalogue of the family-group, genus-group and species-group names of the Odonata of the World. 3rd ed. Urbana, IL: Bridges C.A.; p. 950.

Cowley J. 1934. Notes on some generic names of Odonata. (Oligoaeschna Selys 1889 replaces Jagoria Karsch 1889). Entomologists' Monthly Magazine. 70: 245.

Fabricius JC. 1775. Systema entomologiae, sistens insectorvm classes, ordines, genera, species, adiectis synonymis, locis, descriptionibvs, observationibvs. Kortii, Flensbvrgi et Lipsiae. p. 1-832.

Fraser FC. 1939. A note on the generic characters of Ictinogomphus Cowley (Odonata). Proc R Entomol Soc (B). 8:21-24.

Fraser FC. 1942. Dr Raymond Wheeler's collection of Odonata from the Federated Malay States with the description of new genera and two new species. Proc R Entomol Soc (B). 11:95-105.

Gentilini G, Peters G. 1993. The Upper Miocene aeshnids of Monte Castellaro, Central Italy, and their relationships to extant species (Odonata: Aeshnidae). Odonatologica. 22:147-178.

Hagen HA. 1863. Neuropteren aus der Braunkohle von Rott im Siebengebirge. Palaeontographica Cassel. 10:247-269.

Hagen HA. 1875. Synopsis of the Odonata of America. Proc Boston Soc Natur Hist. 18:20-96.

Handlirsch A. 1906-1908. Die fossilen Insekten und die Phylogenie der rezenten Formen. Ein Handbuch für Paläontologen und Zoologen. 1430. Leipzig [published in parts between 1906 and 1908 as follows: pp. i-vi, 1-160, pls. 1-9 (May 1906); pp. 161-320, pls. 10-18 (June 1906); pp. 321-480, pls. 19-27 (August 1906); pp. 481-640, pls. 28-36 (October 1906); pp. 641-800, pls. 37-45 (February 1907); pp. 801-960, pls. 46-51 (June 1907); pp. 961-1120 (November 1907); pp. 1121-1280 (January 1908); pp. vii-ix, 1281-1430 (July 1908). Dated from publication information given on p. ix.]. Engelman: V.W. publ.

Heer O. 1849. Die Insektenfauna der Tertiärgebilde von Eningen und von Radoboj in Croatien. In: Liepzig EW, editor. Zweite Abtheilung: Heuschrecken, Florfliegen, Aderflüger, Schmetterlinge und Fliegen. Schweiz: N. Denkschr; p. 1-264. Gesell. Gesammt. Naturwiss. 11: iv.

Jacobson G, Bianchi V. 1905. Die Orthopteren und Pseudoneuropteren des Russischen Reiches und der angrenzenden Gebiete. St. Petersburg: A. F. Dewrien; p. 635-846. [In Russian].

Kirby WF. 1890. A synonymic catalogue of Neuroptera Odonata, or dragonflies. With an appendix of fossil species. London: Gumey \& Jackson; ix + p. 1-202.

Knor S, Kvaček Z, Wappler T, Prokop J. 2015. Diversity, taphonomy and palaeoecology of plantarthropod interactions in the lower Miocene (Burdigalian) in the Most Basin in north-western Bohemia (Czech Republic). Rev Palaeobot Palynol. 219:52-70.

Knor S, Prokop J, Kvaček Z, Janovský Z, Wappler T. 2012. Plant-Arthropod associations from the Early Miocene of the Most Basin in North Bohemia - Palaeoecological and palaeoclimatological implications. Palaeogeogr Palaeoclimat Palaeoecol. 321-322:102-112.

Kukalová-Peck J. 1991. Fossil history and the evolution of hexapod structures. pp.: 141-179. In: CSIRO (editor.) The insects of Australia, a textbook for students and research workers. 2nd ed. Vol. 1. Melbourne: Melbourne University Press. p. 542.

Kvaček Z, Böhme M, Dvořák Z, Konzalová M, Mach K, Prokop J, Rajchl M. 2004. Early Miocene freshwater and swamp ecosystems of the Most Basin (northern Bohemia) with particular reference to the Bílina mine section [Spodnomiocenní sladkovodní a bažinné ekosystémy mostecké pánve (severní Čechy) se zvláštním zřetelem k profilu dolu Bílina]. J Czech Geol Soc. 49:1-40.

Kvaček Z, Hurník S. 2000. Revision of Miocene plants preserved in baked rocks in the North Bohemian Tertiary. Acta Mus Nat Pragae (B). 56:1-48.

Kvaček Z, Walther H. 1998. The Oligocene volcanic flora of Kundratice near Litoměřice, České Středohoří volcanic complex (Czech Republic) - a review. Acta Mus Nat Pragae (B). 54:1-42.

Leach WE. 1815. Entomology. Brewster D, editor. The Edinburgh Encyclopaedia. 9:57-172.

Li Y-J, Nel A, Ren D, Pang H. 2011a. A new genus and species of hawker dragonfly of uncertain affinities from the Middle Jurassic of China (Odonata: Aeshnoptera). Zootaxa. 2927:57-62.

Li Y-J, Nel A, Ren D, Zhang B-L, Pang H. 2011b. New discoveries of Neogene hawker dragonflies (Insecta, Odonata, Aeshnidae) from Shandong province in China. Zoosystema. 33:577-590. 
Martin R. 1908-1909. Aeschnines. Collections zoologiques du Baron Edm. de Selys Longchamps, Catalogue systématique et descriptif. Brussels: Hayez, Impr. Des Académies; p. 85-156. 18 and 19:1-84.

Matys Grygar T, Mach K. 2013. Regional chemostratigraphic key horizons in the macrofossil-barren siliciclastic lower Miocene lacustrine sediments (Most Basin, Eger Graben, Czech Republic). Bull Geosciences. 88:557-571.

Needham JG. 1944. Further studies on Neotropical Gomphine dragonflies (Odonata). Trans Am Entomol Soc. 69:171-224.

Nel A, Martínez-Delclòs X, Escuillié F, Brisac P. 1994. Les Aeshnidae fossiles: etat actuel des connaissances (Odonata, Anisoptera). N Jb Geol Paläont, Abh. 194:143-186.

Nel A, Paicheler JC. 1992. Les Odonata fossiles: état actuel des connaissances. Deuxième partie: les Petaluridae et Cordulegastridae fossiles (Odonata, Anisoptera, Petaluroidea). Nouv Rev Entomol. 9:305-323.

Nel A, Paicheler JC. 1993. Les Libellulidae fossiles. Un inventaire critique (Odon., Anisoptera, Libelluloidea). Entomol Gallica. 4:166-190.

Nel A, Paicheler JC. 1994a. Les Gomphidae fossiles. Un inventaire critique (Odonata, Gomphidae). Ann Soc Entomol Fr (N.S.). 30:55-77.

Nel A, Paicheler JC. 1994b. Les Libelluloidea fossiles autres que Libellulidae. Un inventaire critique (Odonata, Corduliidae, Macromiidae, Synthemistidae, Chlorogomphidae et Mesophlebiidae). Nouv Rev Entomol. 11:321-334.

Nel A, Petrulevičius JF, Jarzembowski EA. 2005. New fossil Odonata from the European Cenozoic (Insecta: odonata: thaumatoneuridae, Aeshnidae, ?ldionychidae, Libellulidae). N Jb Geol Paläont, Abh. 235:343-380.

Papp A, Mandl K. 1951. Insekten aus den Congerienschichten des Wiener Beckens. Sber Oesterr Akad Wiss, Math-Naturwiss Kl. 160:295-302.

Pinhey E. 1964. Dragonflies (Odonata) of the Angola-Congo borders of Rhodesia. Publ Cult Comp Diam Angola. 63:97-130.

Prokop J. 2003. Remarks on palaeoenviromental changes based on reviewed Tertiary insect associations from the Krušné hory piedmont basins and the Ceské stredohorí Mts in northwestern Bohemia (Czech Republic). Acta Zool Cracov. 46:329-344. (suppl. - Fossil Insects).

Prokop J, Fikáček M. 2007. Early Oligocene insect fauna from Seifhennersdorf (Saxony, Germany). Acta Mus Nat Pragae (B). 63:209-217.

Prokop J, Fleck G, Nel A. 2003. New dragonflies from the Lower Miocene (Ottnagian/Karpatian) of the Cypris Shale in western Bohemia (Odonata: libellulidae). N Jb Geol Paläont, Mh. 2003:561576.

Prokop J, Nel A. 2000. Merlax bohemicus gen. n., sp. n., a new fossil dragonfly from the Lower Miocene of northern Bohemia (Odonata: Aeshnidae). Eur J Entomol. 97:427-431.

Prokop J, Nel A. 2002. New Tertiary dragonflies from Lower Oligocene of the České středohoři Mts and Lower Miocene of the Most Basin in the Czech Republic (Odonata: Anisoptera). Acta Soc Zool Bohem. 66:141-150.

Prokop J, Přikryl T, Dostál O, Nel A. 2007. Oligaeschna kvaceki sp. nov., a new fossil dragonfly (Odonata: Aeshnidae) from the Middle Oligocene of northern Moravia (Western Carpathians). Geol Carpathica. 58:181-184.

Prokop J, Wappler T, Knor S, Kvaček Z. 2010. Plant-arthropod associations from the Lower Miocene of the Most Basin in northern Bohemia (Czech Republic): A preliminary report. Acta Geol Sinica. 84:903-914.

Riek F, Kukalová-Peck J. 1984. A new interpretation of dragonfly wing venation based upon early Upper Carboniferous fossils from Argentina (Insecta: Odonatoidea) and basic character states in pterygote wings. Can J Zool. 62:1150-1166.

Říha P. 1977. Tercierní hmyz chebské a sokolovské pánve. In: Holý F, editor. Sborník 8. celostátní paleontologické konference v Sokolově. kvetna: Propag; p. 24-25. p. 19-22.

Riou B, Nel A. 1995. Nouveaux Odonates fossiles du Miocène supérieur de l'Ardèche. (Odonata: Sieblosiidae, Lestidae, Libellulidae, Corduliidae, Aeshnidae). Trav EPHE, Biol Evol Insectes Paris. 7/8:125-144. 
Scudder SH. 1890. The fossil insects of North America (with notes on some European species). 2. The Tertiary insects. Report US Geol Surv Territories. 13:1-734.

Teodoridis V, Kvaček Z. 2006. Palaeobotanical research of the Early Miocene deposits overlying the main coal seam (Libkovice and Lom Members) in the Most Basin (Czech Republic). Bull Geosciences. 81:93-113.

Von Ellenrieder N. 2002. A phylogenetic analysis of the extant Aeshnidae (Odonata: anisoptera). Syst Entomol. 27:437-467.

Walther H, Kvaček Z. 2007. Early Oligocene flora of Seifhennersdorf (Saxony). Acta Mus Nat Pragae (B). 63:85-174.

Yasuno T. 1990. A fossil dragonfly Ictinogomphus from the Miocene Ito's formation, Fukui prefecture, Central Japan. Bull Japan Sea Res Inst, Kanazawa Univ. 22:49-54.

Zhang HM, Cai QH. 2014. Aeshna shennong sp. nov., a new species from Hubei Province, China (Odonata: Anisoptera: Aeshnidae). Zootaxa. 3795:489-493.

Zhang J. 1989. Fossil insects from Shanwang, Shandong, China. Jinan: Shandong Science and Technology Publishing House; p. 1-459. [in Chinese with English abstract]. 